Materials and Components

Technology Division

Materials and Components

Technology Division

Materials and Components

Technology Division

Materials and Components

Technology Division

Materials and Components

Technology Division

Materials and Components

Technology Division

Materials and Components

Technology Division

Materials and Components

Technology Division

Materials and Components

Technology Division

Materials and Components

Technology Division

Materials and Components

Technology Division

Materials and Components

Technology Division

Materials and Components

Technology Division

Materials and Components

Technology Division Materials and Components

Technology Division Materials and Components

Technology Division Materials and Components

Technology Division

by T. M. Kuzay, H. J. Halle, and K. E. Kasza
Preliminary Review of Mass Transfer and Flow Visualization Studies and Techniques Relevant to the Study of Erosion-Corrosion of Reactor Piping Systems

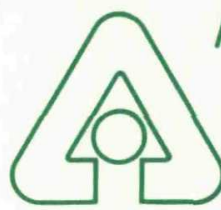

Argonne National Laboratory, Argonne, Illinois 60439

operated by The University of Chicago

Prepared for the Office of Nuclear Regulatory Research

U. S. Nuclear Regulatory Commission under Interagency Agreement DOE 40-550-75

Materials and Components

Technology Division

Materials and Components

Technology Division

Materials and Components

Technology Division

Materials and Components

Technology Division

Receive? :

'AUG 12 , 58 


\section{DISCLAIMER}

Portions of this document may be illegible in electronic image products. Images are produced from the best available original document. 
Argonne National Laboratory, with facilities in the states of Illinois and Idaho, is owned by the United States government, and operated by The University of Chicago under the provisions of a contract with the Department of Energy.

\section{NOTICE}

This report was prepared as an account of work sponsored by an agency of the United States Government. Neither the United States Government nor any agency thereof, or any of their employees, makes any warranty, express or implied, or assumes any legal liability or responsibility for any third party's use, or the results of such use, of any information, apparatus, product or process disclosed in this report, or represents that its use by such third party would not infringe privately owned rights.

Available from

Superintendent of Documents

U. S. Government Printing Office

Post Office Box 37082

Washington, D.C. 20013-7982

and

National Technical Information Service

Springfield, VA 22161 


\section{DISCLAIMER}

This report was prepared as an account of work sponsored by an agency of the United States This report was Government. Neither the Unity, express or implied, or assumes any legal liability or respot, or employees, makes any waccleteness, or usefulness of any information, appaned rights. Referbility for the accuracy, compents that its use would not infringe private name, trademark, process disclosed, or reprific commercial product, process, or service by its endorsement, recomence herein to any specific constitute or imply not necessarily constereof. The views manufacturer, or otherwise doe United States Government or any agency thect those of the

mendation, or favoring by the United States herein do not
and opinions of authors expressed hered
United States Government or any agency thereof.

NUREG/CR - 5131

ANL - 88 - 20

(Distribution

Code: R5)

NUREG/CR--5131

ARGONNE NATIONAL LABORATORY

9700 South Cass Avenue

Argonne, Illinois 60439

\author{
PRELIMINARY REVIEW OF MASS TRANSFER AND \\ FLOW VISUALIZATION STUDIES AND \\ TECHNIQUES RELEVANT TO THE STUDY OF \\ EROSION-CORROSION OF REACTOR PIPING SYSTEMS
}

by

T. M. Kuzay, H. J. Halle, and K. E. Kasza

\section{TI88 014910}

June 1988

\footnotetext{
Prepared for the Division of Engineering Technology

Office of Nuclear Regulatory Research

U.S. Nuclear Regulatory Commission

Washington, D.C. 20555

Under Interagency Agreement DOE 40-550-75
}

NRC FIN No. A2212 


\title{
PRELIMINARY REVIEW OF MASS TRANSFER AND \\ FLOW VISUALIZATION STUDIES AND \\ TECHNIQUES RELEVANT TO THE STUDY OF \\ EROSION-CORROSION OF REACTOR PIPING SYSTEMS*
}

\begin{abstract}
This report provides some background information on the failed piping at the Surry-2 reactor; a summary of pertinent literature on mass transfer in related geometries; and a description of methodologies for visualization and erosion rate measurements in laboratory model studies that can provide greater insight into the role of flow geometry in erosioncorrosion.
\end{abstract}


Table of Contents

Page

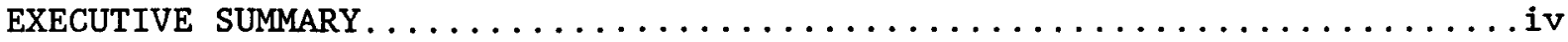

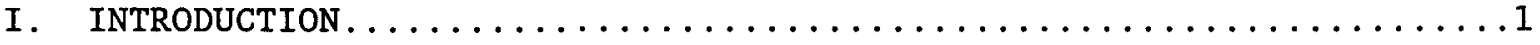

II. REVIEW OF STATE OF THE ART..............................

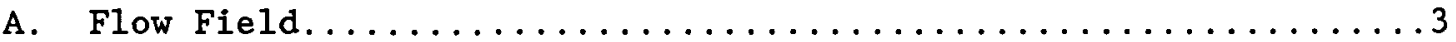

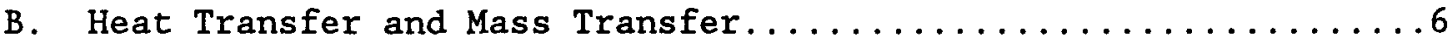

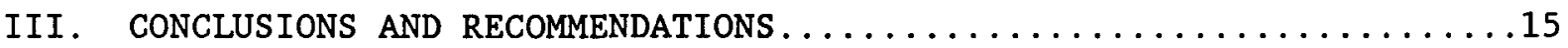

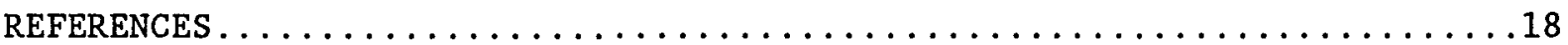




\section{EXECUTIVE SUMMARY}

A failed combination piping tee and $90^{\circ}$ elbow at the Surry-2 Reactor will be simulated in a laboratory model to investigate the associated flow hydrodynamics and to quantify the mass transfer rates during erosion. Both flow visualization and quantifiable mass transfer techniques are suggested to obtain localized information.

An extensive literature survey on the state of the art has resulted in the following conclusions and recommendations:

(1) The new data on locally measured mass transfer rates in piping and other elements (entrances, elbows, restrictions) reveal that the link between the mass transfer coefficient and the resulting pipe wall wear is much stronger than was previously assumed.

(2) It is erroneous to work with the average, fully developed mass transfer values in correlating relative erosion-corrosion severity in pipe components with mass transfer rates in the resolution of specific failure problems.

(3) It is equally erroneous to attribute a general geometry factor " $\mathrm{K}$ " to complex piping interfaces to characterize their "propensity for erosion-corrosion." Although this procedure is allowable as a general-purpose engineering practice, it results in a nonconservative approach in designing specific geometries in critical cases. What is truly needed is localized information on the mass transfer coefficients in these complex and critical interfaces.

(4) Therefore, specific geometries (splits, tees, crosses, etc.) should be studied experimentally to obtain mass transfer maps on a local basis.

(5) Among the techniques that are available to do the above studies, the plaster dissolution technique is inexpensive, simple, and amenable to intricate casting, and is therefore highly recommended.

(6) A comprehensive multi-year program is needed to catalog the local data from direct measurements on selected critical geometries commonly found in power plant piping. Such data are woefully lacking 
and appear to be the key element in the resolution of erosioncorrosion concerns in PWR piping systems and in process industries. 
PRELIMINARY REVIEW OF MASS TRANSFER AND

FLOW VISUALIZATION STUDIES AND

TECHNIQUES RELEVANT TO THE STUDY OF

EROSION-CORROSION OF REACTOR PIPING SYSTEMS

by

T. M. Kuzay, H. J. Halle, and K. E. Kasza

\section{INTRODUCTION}

The Surry-2 reactor experienced breakage in a main feedwater suction pipe of the steam generator and a missile release from the broken area. ${ }^{1}$ Figure 1 depicts an overall schematic diagram of the failed pipe configuration. The main pipe is a 24-inch-diameter (0.625-inch wall thickness), SA 106 Grade B steel pipe. The $90^{\circ}$ nozzle from it is an 18 -inch-diameter, 0.500-inch-thick steel saddle piece welded to the pipe. The reported length of the nozzle is 18 inches (one hydraulic diameter). A $90^{\circ}$ elbow pipe is welded to the nozzle. The elbow is a seamless SA 234 WPB steel piece (the same as SA 106 Grade $B)$ with 27 -inch bend radius. The radius ratio of the elbow $(R / r=27 / 9)$ is 3.0 .

The configuration of the piping at Surry-2 is believed to have played a major role in establishing conditions that promoted erosion-corrosion of the pipe wall. The pipe failure occurred on the intrados of a $90^{\circ}$ (long radius), 18-inch-diameter elbow that branched from a 24-inch-diameter flow-splitting tee. The temperature of the feedwater at the time of the Surry reactor pipe failure was $374^{\circ} \mathrm{F}$ at $367 \mathrm{psi}$, which represented a $50^{\circ} \mathrm{F}$ subcooling. The average bulk flow velocity of the water was $17 \mathrm{ft} / \mathrm{sec}$ in the 18 -inch branch and $12 \mathrm{ft} / \mathrm{sec}$ in the 24 -inch header. The elbow-tee configuration is an undesirable design arrangement that is believed to have caused direct flow impingement on the inside elbow intrados and to have established secondary flow paths in the elbow, causing even higher turbulent flow velocities. Recommended industry practice typically limits bulk flow velocities in singlephase (water) systems to less than $10 \mathrm{ft} / \mathrm{sec}$. However, flow velocities as high as $50 \mathrm{ft} / \mathrm{sec}$ are reported in some piping systems in foreign facilities with no apparent detrimental effects.

To conduct this initial investigation of the factors influencing the Surry failure, an extensive, computer-aided literature search was 


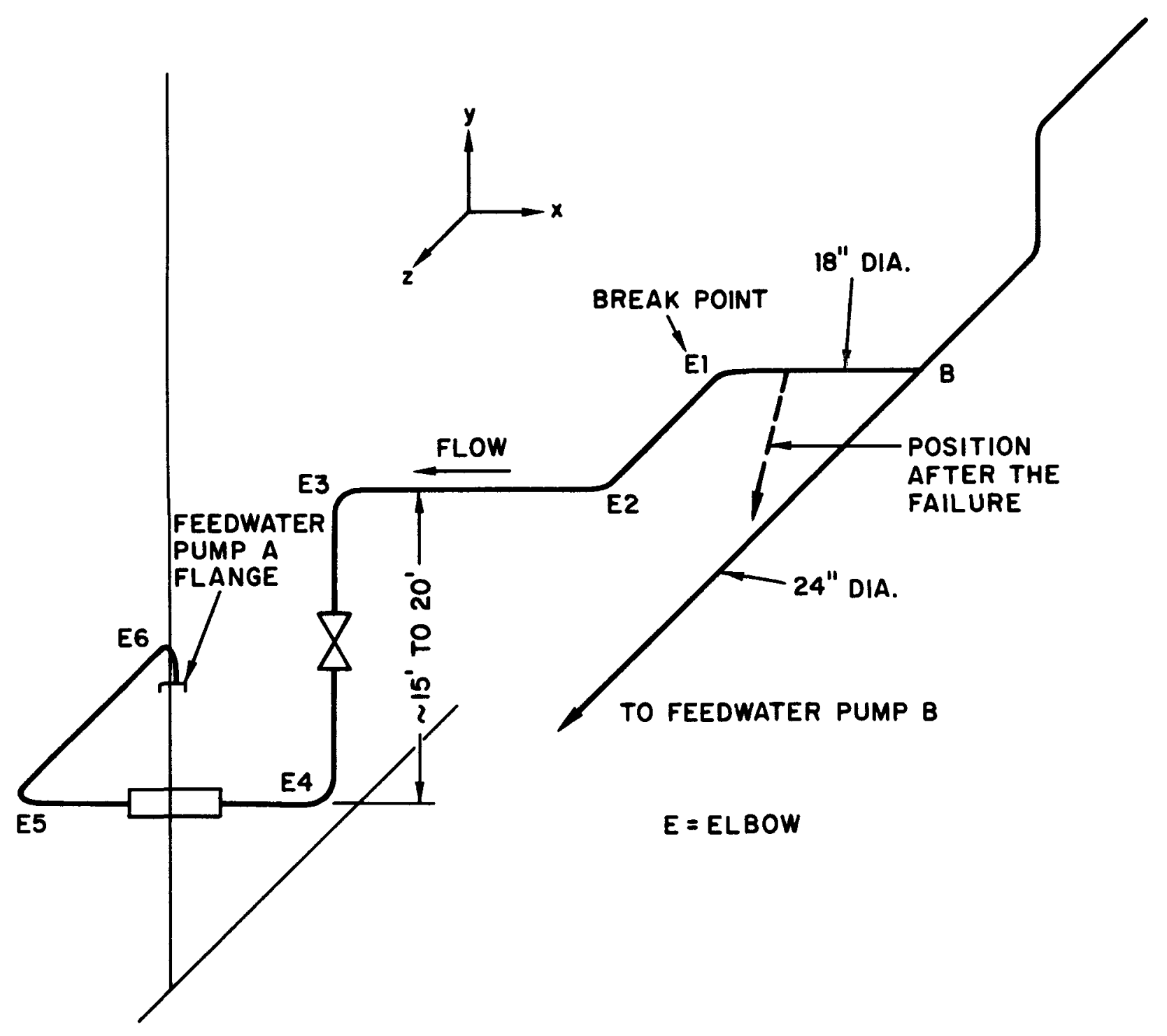

Fig. 1. Surry pipe configuration and failure details. 
undertaken. The following data bases were scanned: DOE, NTIS (National Technical Information Service), NASA, Compendix (Engineering Index), and a British data base. In addition, a personal search was conducted. Subjects involved in the literature search included the following:

(1) Flow field (primary and secondary flow) in curved pipes, both experimental (i.e., flow visualization) and theoretical.

(2) Heat transfer in curved pipes, usually on an overall but also, to a very limited extent, on a local basis.

(3) Mass transfer; application of the heat-mass transfer analogy; and heat-mass transfer experimental techniques, e.g., electrochemical methods, naphthalene sublimation, plaster dissolution, melting point surface coatings, liquid crystal overlays, and infrared measurements.

(4) Erosion-corrosion and factors influencing it such as pipe material, oxygen content, $\mathrm{pH}$, combination with flow field, possible aggravation by flow separation, and industrial experience.

The collected literature covers some of the fundamental research on elbow flow, heat transfer, and mass transfer and is very useful in assessing the possible importance of various factors influencing the Surry failures, but it provides no direct, definitive, quantifiable information on the Surry erosioncorrosion elbow thinning.

\section{REVIEW OF STATE OF THE ART}

To evaluate the state of the art in the understanding of hydrodynamics and its relation to erosion-corrosion as represented by the collected literature, selected references were reviewed in detail. Some of the pertinent details are summarized in Table 1.

\section{A. Flow Field}

The heat and mass transfer associated with fluid flow in curved pipes differs considerably from that in straight pipes because of centrifugal-forceinduced secondary flows superimposed on the main flow. The investigations reported in the literature on flow fields cover curved pipes of many different designs. The studies were theoretical as well as experimental. 
Table 1. SELECTED MASS TRANSFER INVESTIGATIONS

AND PERTINENT PARAMETERS

\begin{tabular}{|c|c|c|c|c|c|c|c|c|c|}
\hline $\begin{array}{l}\text { Ref. } \\
\text { No. }\end{array}$ & Subj . ${ }^{a}$ & Fluid & $\begin{array}{l}\text { Type of } \\
\text { Investi- } \\
\text { gation }\end{array}$ & Run & $\begin{array}{l}\text { Cross } \\
\text { Shape }\end{array}$ & $\begin{array}{r}\text { ection } \\
\text { Size } \\
(\mathrm{mm})\end{array}$ & $\begin{array}{l}\text { Radius } \\
\text { Ratio } \\
(R / r)\end{array}$ & $\begin{array}{l}\text { Velocity } \\
(\mathrm{m} / \mathrm{s})\end{array}$ & $10^{-3} \mathrm{Re}$ \\
\hline 1 & $\begin{array}{l}\mathrm{MT} \\
\mathrm{E} / \mathrm{C}\end{array}$ & Water & Anal. & $\begin{array}{l}2 \mathrm{ea} . \\
90^{\circ}\end{array}$ & Circ. & 457 & $\mathrm{ND}^{\mathrm{C}}$ & 5.2 & 16,000 \\
\hline 2 & MT & Water & $\begin{array}{l}\text { Plaster } \\
\text { Dissol. }\end{array}$ & Straight & Rect. & {$[298]^{d}$} & -- & $0.15-0.85$ & $8-99$ \\
\hline 3 & MT & Water & $\begin{array}{l}\text { Plaster } \\
\text { Dissol. }\end{array}$ & Straight & Square & 152 & -- & 1.13 & 22.4 \\
\hline 4 & MT & Air & $\begin{array}{l}\text { Napht. } \\
\text { Sub1. }\end{array}$ & $90^{\circ}$ & Circ. & 70 & 2.83 & 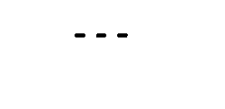 & $50-400$ \\
\hline \multirow[t]{2}{*}{5} & MT & Water & $\begin{array}{l}\text { Electro- } \\
\text { chem. }\end{array}$ & $180^{\circ}$ & Circ. & 37 & 7 & -- & $0.37-7.6$ \\
\hline & & & & Straight & Circ. & 38 & $\cdots$ & $\cdots$ & $0.37-1.7$ \\
\hline \multirow[t]{2}{*}{6} & $\mathrm{HT}$ & Air & $\begin{array}{l}\text { Melting } \\
\text { Pt. Surf. }\end{array}$ & $90^{\circ}$ & Rect. & $38 \times 13$ & $2 \& 3$ & $\ldots$ & 19.6 \\
\hline & FV & Air & $\begin{array}{l}\text { Ink Dot } \\
\text { Matrix }\end{array}$ & $90^{\circ}$ & Rect. & $38 \times 13$ & $2 \& 3$ & $\ldots$ & 19.6 \\
\hline 7 & $\begin{array}{l}\mathrm{MT} \\
\mathrm{E} / \mathrm{C}\end{array}$ & Water & Review & Straight & Circ. & 19 & $\cdots$ & $0.13-0.81$ & $4.1-24.8$ \\
\hline \multirow[t]{2}{*}{8} & MT & Air & $\begin{array}{l}\text { Napht. } \\
\text { Sub1. }\end{array}$ & $\begin{array}{l}30,60 \\
90^{\circ}\end{array}$ & Circ. & 32 & 9 & $\cdots$ & $5-100$ \\
\hline & FV & Air & $\begin{array}{l}\text { Oil- } \\
\text { lampblack }\end{array}$ & $90^{\circ}$ & Circ. & 32 & 9 & $\cdots$ & 100 \\
\hline
\end{tabular}

$\mathrm{a}_{\mathrm{E} / \mathrm{C}}=$ Erosion-Corrosion, FV = Flow Visualization; HT = Heat Transfer,

$\mathrm{MT}=$ Mass Transfer

$\mathrm{b}_{\mathrm{R} / \mathrm{r}}=$ Ratio of bend to conduit radii.

$c_{\mathrm{ND}}=$ No or incomplete data.

$\mathrm{d}_{\text {Numbers }}$ in brackets are estimates. 


\begin{tabular}{|c|c|c|c|c|c|c|c|c|}
\hline $\begin{array}{l}\text { Ref. } \\
\text { No. }\end{array}$ & $\mathrm{Nu}$ & Sh & $\mathrm{Sc}$ & $\begin{array}{l}\text { Diffusivity } \\
\left(10^{-3} \mathrm{~mm}^{2} / \mathrm{s}\right)\end{array}$ & $\begin{array}{l}\text { K Mass } \\
\text { Trans. } \\
(\mathrm{mm} / \mathrm{s})\end{array}$ & $\begin{array}{l}\text { Erosion } \\
\text { Rate } \\
\text { (mm/s) R }\end{array}$ & Resolution & Comments \\
\hline 1 & $\cdots$ & {$[69,000]$} & [19.5] & 7.7 & {$[3.6]$} & {$\left[3.5 \times 10^{-8}\right]$} & ] Overall & $\cdots$ \\
\hline 2 & $\cdots$ & $\cdots$ & $\cdots$ & -- & -- & {$\left[1.9 \times 10^{-5}\right]$} & Local & -- \\
\hline 3 & 1140 & {$[259,000]$} & 875 & 0.9 & {$[12.2]$} & $\cdots$ & Local & $\begin{array}{l}\text { Typical } \\
\text { data }\end{array}$ \\
\hline 4 & $\cdots$ & {$[150-1500]$} & 2.53 & $\cdots$ & $\cdots$ & -- & Local & -- \\
\hline 5 & $\cdots$ & $-\cdots$ & 1680 & 0.633 & $\cdots$ & -- & Local & $\begin{array}{l}\text { Probably } \\
\text { all } \\
\text { laminar }\end{array}$ \\
\hline 6 & {$[30-60]$} & $\cdots$ & -- & -- & $\cdots$ & $\cdots$ & Local & -- \\
\hline & -- & -- & -- & -- & -- & $\cdots$ & Local & --- \\
\hline 7 & $\cdots$ & {$[95-430]$} & 238 & {$[2.61]$} & $\begin{array}{l}{[0.013-} \\
0.060]\end{array}$ & $\cdots$ & Overall & $\cdots$ \\
\hline \multirow[t]{2}{*}{8} & -- & $\cdots$ & 2.5 & {$[6000]$} & --- & $\cdots$ & Ax./Cir. ${ }^{f}$ & $\cdots$ \\
\hline & $\cdots$ & -- & $\cdots$ & -- & $\cdots$ & $\cdots$ & Local & $\ldots$ \\
\hline
\end{tabular}

eMass transfer of iron compounds unless otherwise indicated.

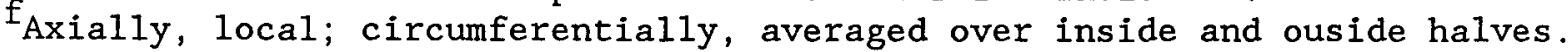


For erosion-corrosion studies, a knowledge of the flow field adjacent to the internal surface of a curved pipe with turbulent flow is very valuable because of the influence of wall mass transfer coefficients on erosioncorrosion. Sparrow and Chrysler ${ }^{8}$ have investigated this flow field by applying an oil-lampblack technique to visualize air flow patterns at $\operatorname{Re}=100,000$ in a 1.25 -inch-diameter, $90^{\circ}$-bend tube. The authors investigated two separate entry conditions: flow delivery via a straight-run hydrodynamic development tube and flow delivery via a sharp-edged inlet. The visualizations revealed not only flow patterns indicative of the secondary flow but also the locations of flow separation and reattachment to the wall for the sharp-edged entry configuration. Because flow separation regions are believed to aggravate pipe erosion, specific information pertinent to the Surry geometry would be very valuable.

Work at Argonne National Laboratory on thermal striping occurring in a $90^{\circ}$, horizontal elbow under transient thermally stratified flow conditions ${ }^{9}$ utilized flow visualization achieved with a laser-fluorescent dye technique to study the secondary flows generated by an elbow. This work highlighted the complexity of the flow downstream from the elbow and the large spatial variation in flow pattern characteristics that can occur around the circumference of a downstream pipe. Flow in reactor pipes is presumably considerably more complex because of the peculiarity of the flow geometries sometimes used.

\section{B. Heat Transfer and Mass Transfer}

The heat and mass transfer analogy that allows the temperature-driven diffusion process of heat transfer to be simulated by the concentration-driven diffusion process of mass transfer is a well-established experimental

technique. Heat transfer experimenters have shown that at times it is simpler to measure mass transfer and then apply the analogy to determine heat transfer rather than to measure heat transfer directly. This is particularly true when curved surfaces or localized measurements are involved, as would be the case for the complex Surry geometry. A commonly used approach is to present the heat and/or mass transfer data as a ratio to the corresponding data obtained from a reference condition. For complex pipe flows, the reference case is usually fully developed flow through a straight, circular pipe for which heat 
and mass transfer performance has been thoroughly investigated and information is readily available. Because of the close relationship between the two transport processes, the heat as well as the mass transfer literature was surveyed.

The collected literature includes a number of theoretical approaches, whose applicability to Surry could not be readily assessed. These studies will be evaluated more thoroughly at a later date. Thus, the literature assessment effort focused mainly on references presenting experimental heat and mass transfer techniques. Choi et a1. ${ }^{5}$ measured local wall shear rates for laminar water flow in about $145^{\circ}$ of a U-bend tube by means of the electrochemical-1imiting-current method. They found that the wall shear may be increased by secondary flows by as much as a factor of eight over that of fully developed Posieuille flow. With increasing Dean number (or, equivalently, with Reynolds number at fixed curvature ratio), the magnitude of the maximum measured shear increased. The maximum shear occurred at about four pipe diameters from the entrance.

Sparrow and Chrysler ${ }^{8}$ used naphthalene sublimation in air flow to make localized mass transfer measurements. They found that the averaged Sherwood number in the cross section of elbow with the sharp-edged entrance could be as high as three to five times the straight-pipe equivalent. These locations were close to the entrance, and the average Sherwood number was highest on the outside half of the elbow. At lower Reynolds numbers in the range $8 \times 10^{3}$ to $22 \times 10^{3}$, the difference in the Sherwood numbers between the inside and outside of the elbow was large. The difference became smaller as Re increased toward 100,000. These numbers represented nonlocal, directly measured mass transfer coefficients. On a localized basis, higher values would be expected.

Recently, British workers have studied these problems extensively.10-18 They have exclusively used plaster-of-Paris models with water flow. The dissolution of this material is limited by mass transfer, and hence it can be used for local mass transfer measurements. Figure 2 shows the test elbow from Reference 11 , a $90^{\circ}$ elbow with $R / r=8.3$. The results at high $\operatorname{Re}$ are summarized $^{11}$ as follows (see Figs. 3 and 4 ):

The outside wall of the bend is indicating a general increase in mass-transfer with distance into the bend [see our Fig. 3]. The mass-transfer is slightly suppressed between 


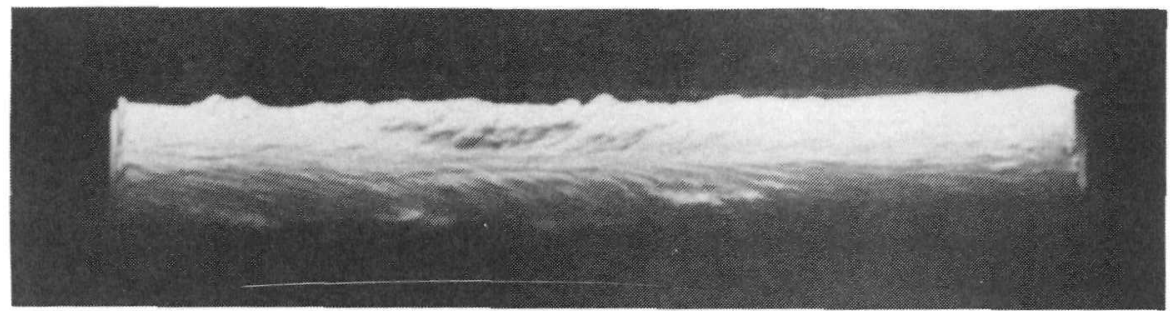

(a) $90^{\circ}$ BEND - $750 \mathrm{cc} / \mathrm{s}\left(\mathrm{Re}_{\mathrm{j}}=46700\right)$ 3.15 HOURS TOTAL RUN TIME

VIEW OF INSIDE WALL

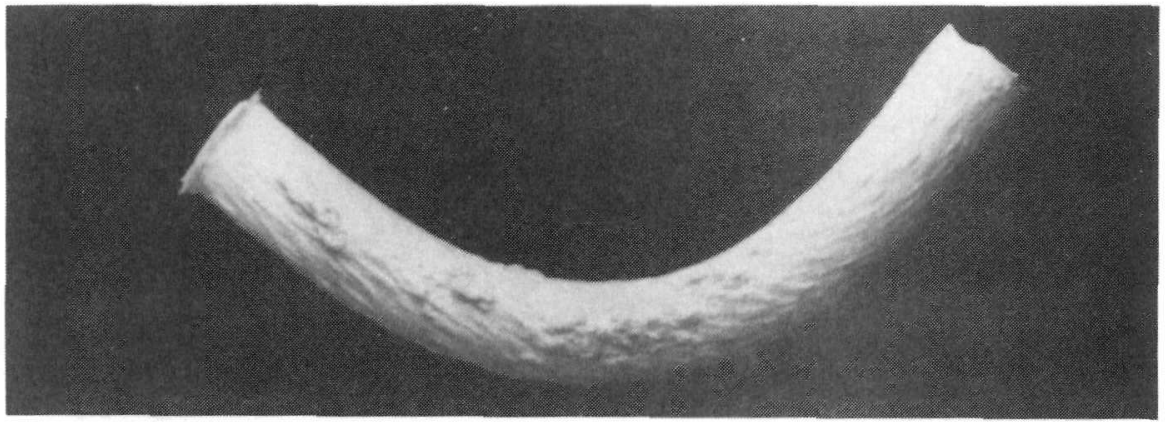

(b) $90^{\circ} \mathrm{BEND}-750 \mathrm{cc} / \mathrm{s}\left(\mathrm{Re}_{\mathrm{i}}=46700\right)$

3.15 HOURS TOTAL RUN TIME

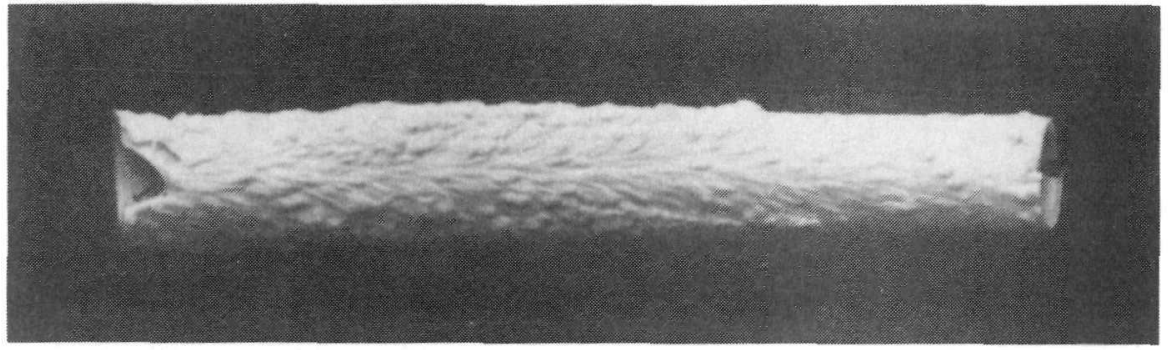

(c) $90^{\circ} \mathrm{BEND}-1000 \mathrm{cc} / \mathrm{s}\left(\mathrm{Re}_{\mathrm{j}}=63000\right)$

VIEW OF INSIDE WALL 4.3 HOURS TOTAL RUN TIME

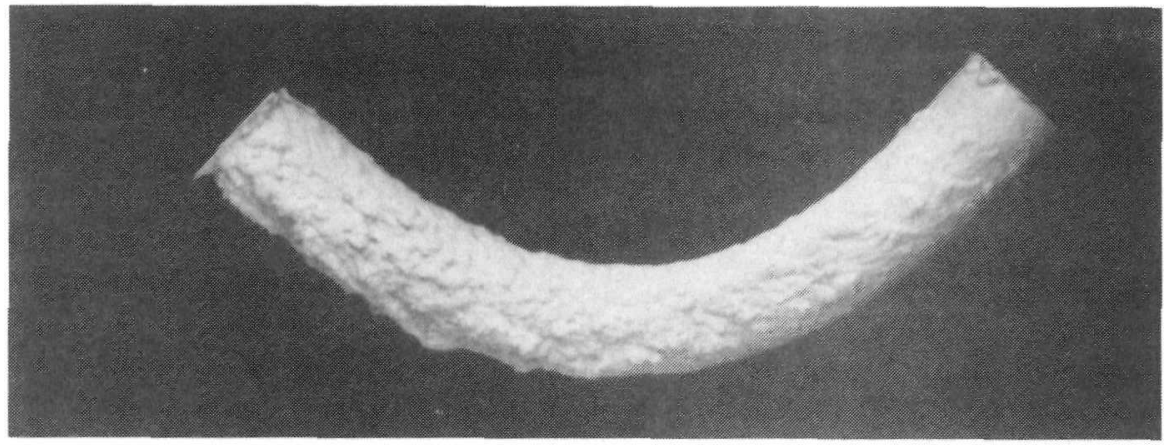

(d) 900 BEND - $1000 \mathrm{cc} / \mathrm{s}\left(\mathrm{Re}_{\mathrm{i}}=63000\right)$

VIEW OF FLANK

4.3 HOURS TOTAL RUN TIME

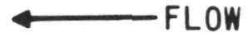

Fig. 2. Photographic views of the test elbow mold after dissolution tests, Reference 11. 

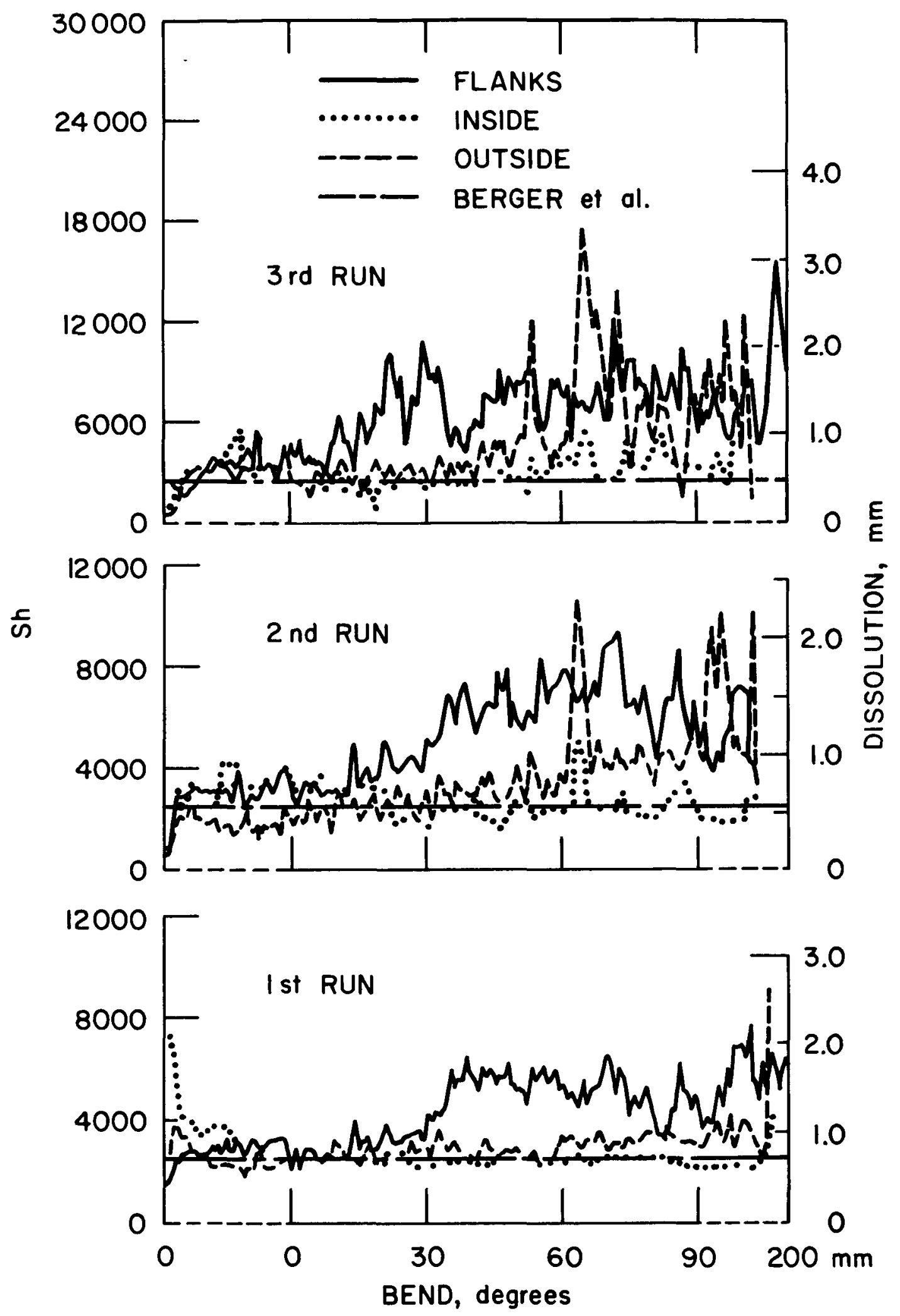

Fig. 3. Mass transfer data on $90^{\circ}$ elbow at $\operatorname{Re}=46,700$, Reference 11 . 


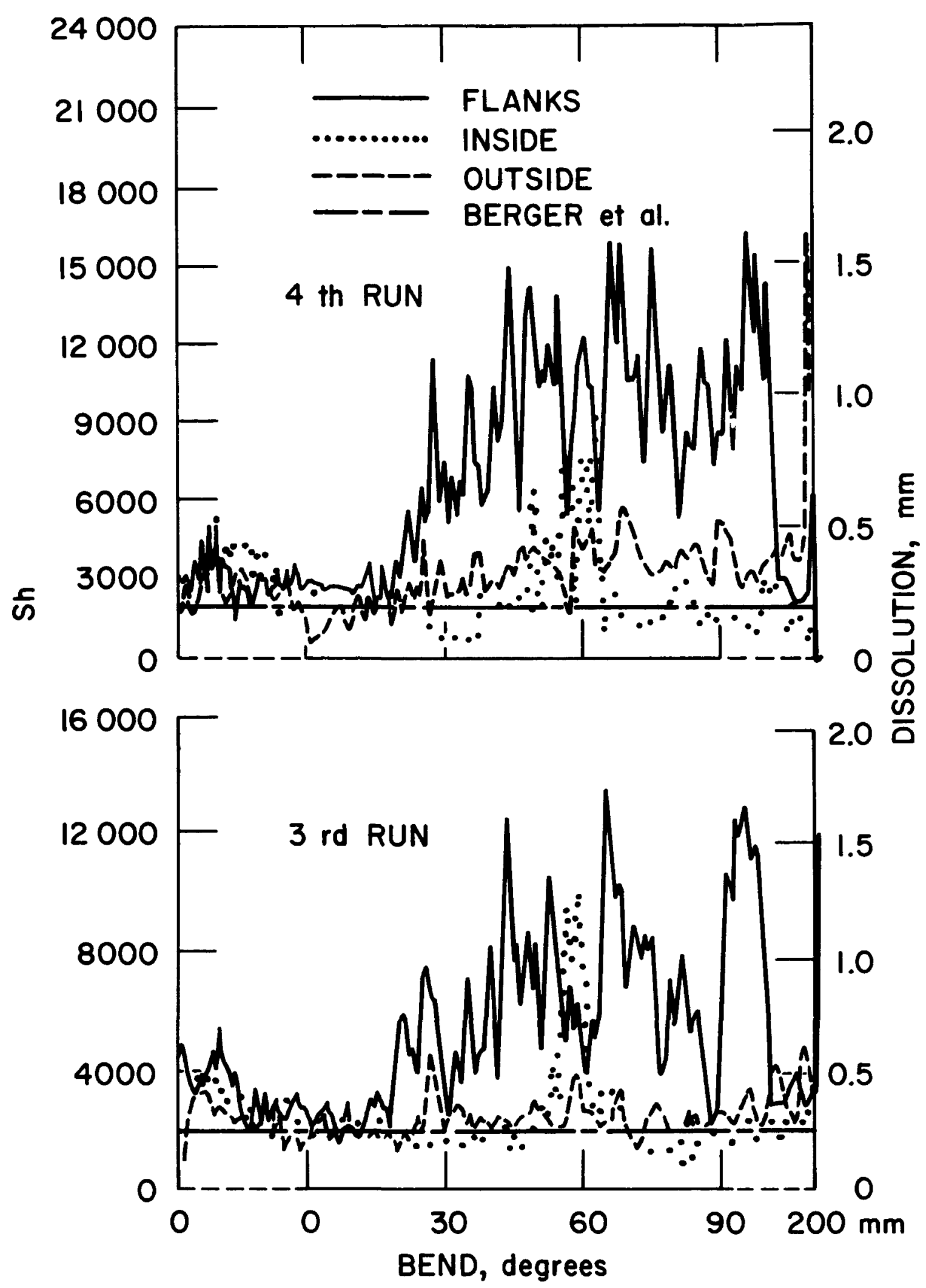

Fig. 4. Mass transfer data on $90^{\circ}$ elbow at $\operatorname{Re}=63,000$, Reference 11 . 
$\theta=0^{\circ}$ and $\theta=20^{\circ}$. This may be due to another, sma11, region of separated flow on the outside of the bend as postulated by Achenbach [our Reference 4]. At the outlet, the enhancement is up to three or more times the straighttube value [see our Fig. 3]. Enhancements even greater than this are seen on the bend flanks. [Our Fig. 4] shows values up to 7 times the straight-tube value downstream of $\theta=45^{\circ}$.

The above values are locally averaged mass transfer values over each quadrant of the cross section that are as high as seven times the value for fully developed mass transfer in a straight tube. On a point-by-point basis, even higher values could be expected.

Additional mass transfer test data were generated by using straight tubes, elbows, and restricted inlets to straight pipes. ${ }^{12}$ One entrance was of the ferruled type, and another had a sharp-edged orifice. The data for the elbow are shown in Fig. 5. The authors ${ }^{12}$ concluded:

The significant increase in the dissolution on the flanks of the bend in subsequent runs was a consistent feature of the high Reynolds Number flows in the $90^{\circ}$ bends. This was assoclated with a characteristic severe roughness pattern which originated on the flanks at about $60^{\circ}$ from the start of the bend and then spread with time, eventually covering the entire bend in some cases. The mass-transfer rate associated with this roughness pattern could be of the order of 6 times the straight tube value.

For the ferrule and the sharp-edged orifice inlet, the maximum mass transfer coefficients measured were 5 and 10 times the average (Figs. 6 and 7).

These data provide independent measurements of the mass transfer coefficients in important piping elements such as elbows and restricted entrances. They conclusively prove that very high local mass transfer coefficients prevail in such geometries and verify the indirect U.S. data 8 that showed that localized high shear zones are present in elbows. The hydrodynamics of flow in elbows, tees, and restricted or complex entrances are important and will produce locally high mass transfer rates, which will significantly impact the erosion-corrosion in such geometries. Furthermore, when two or more nonstraight pipe components are in close proximity, the flow field can be extremely complex, so that it becomes increasingly difficult to predict wall regions of probable high mass transfer. 


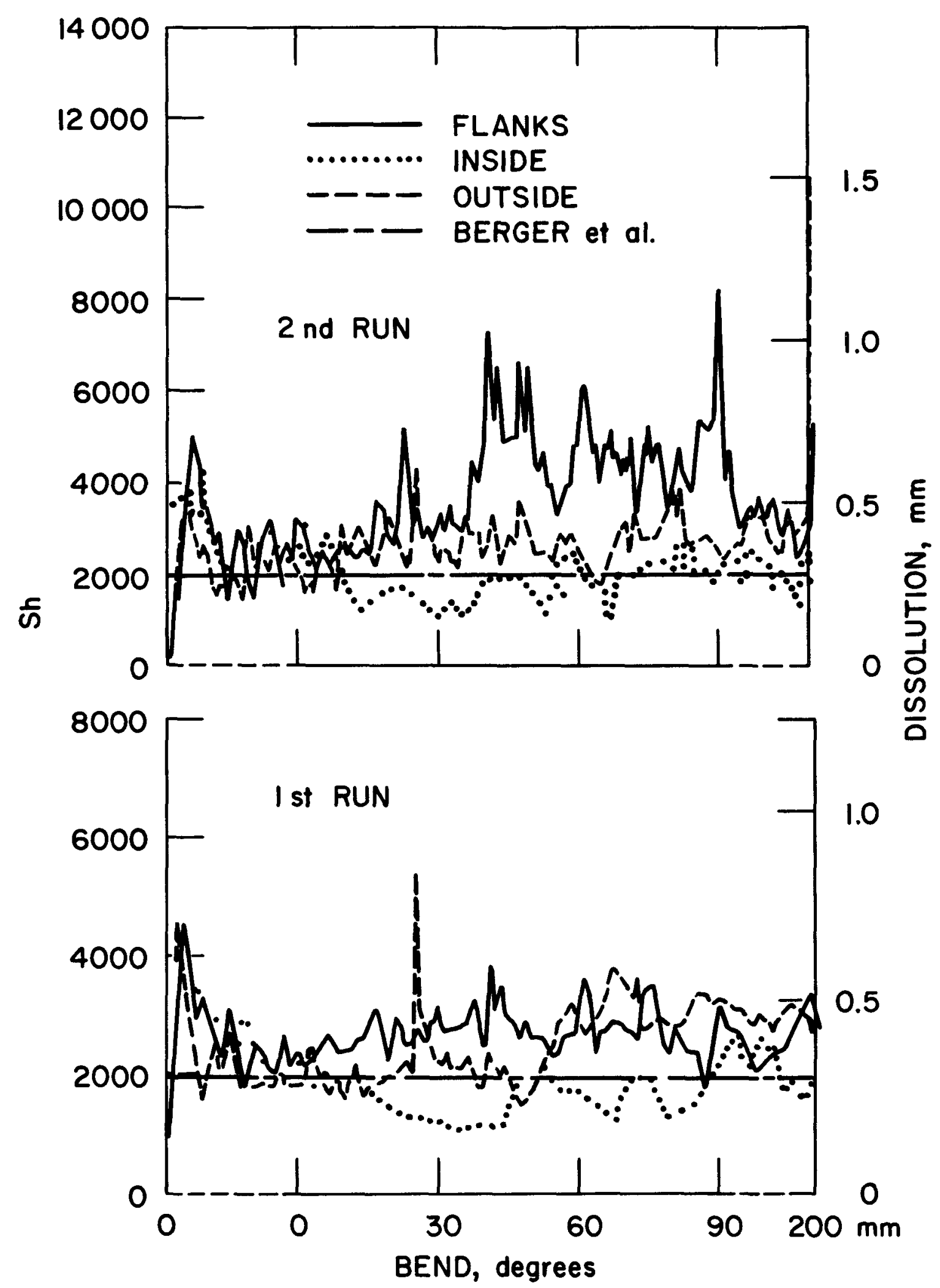

Fig. 5. Renewed mass transfer data on $90^{\circ}$ elbow at $\operatorname{Re}=46,700$, early termination test, Reference 12. 


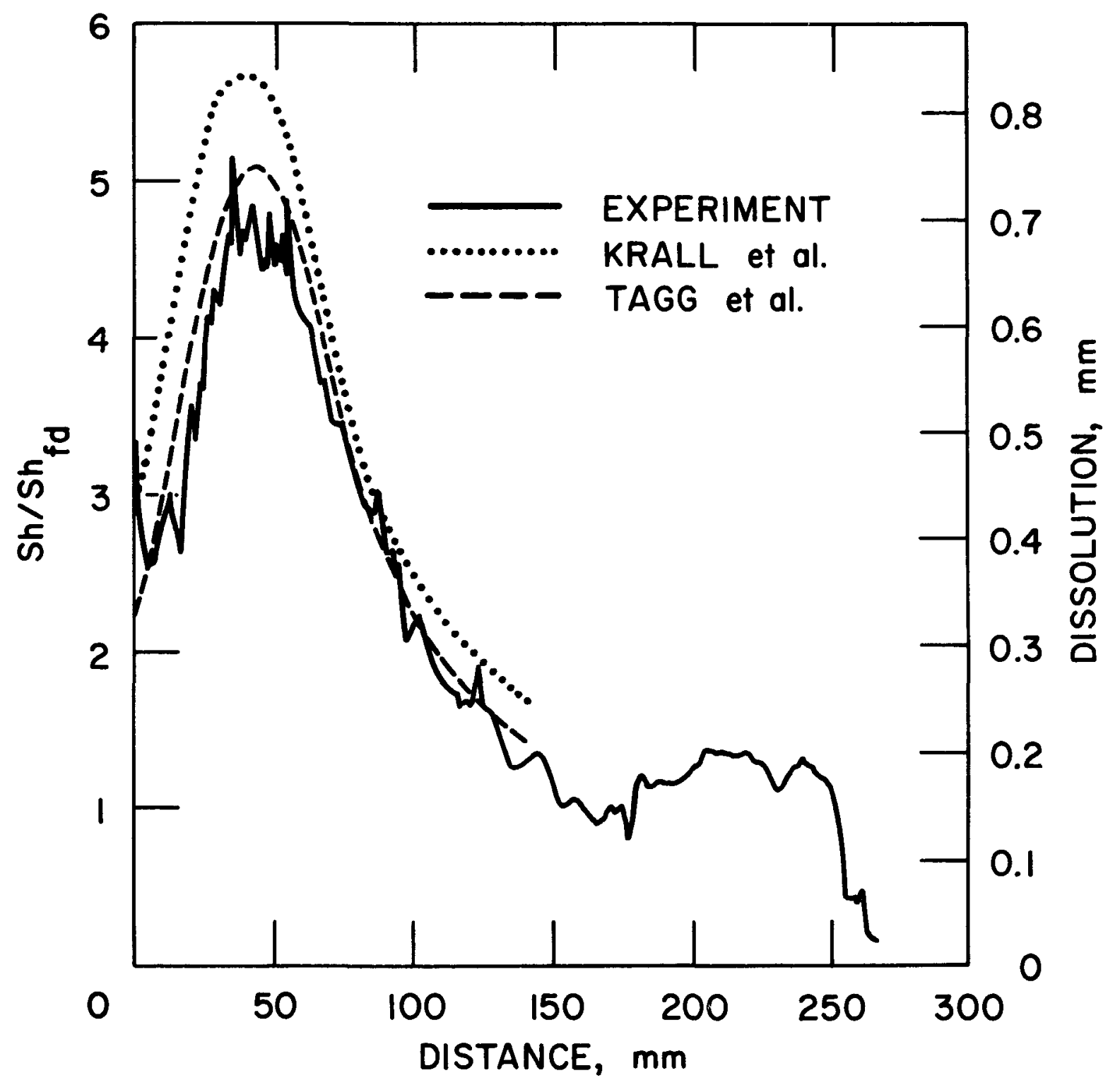

Fig. 6. Mass transfer data on ferruled entrance pipe, Reference 12. 


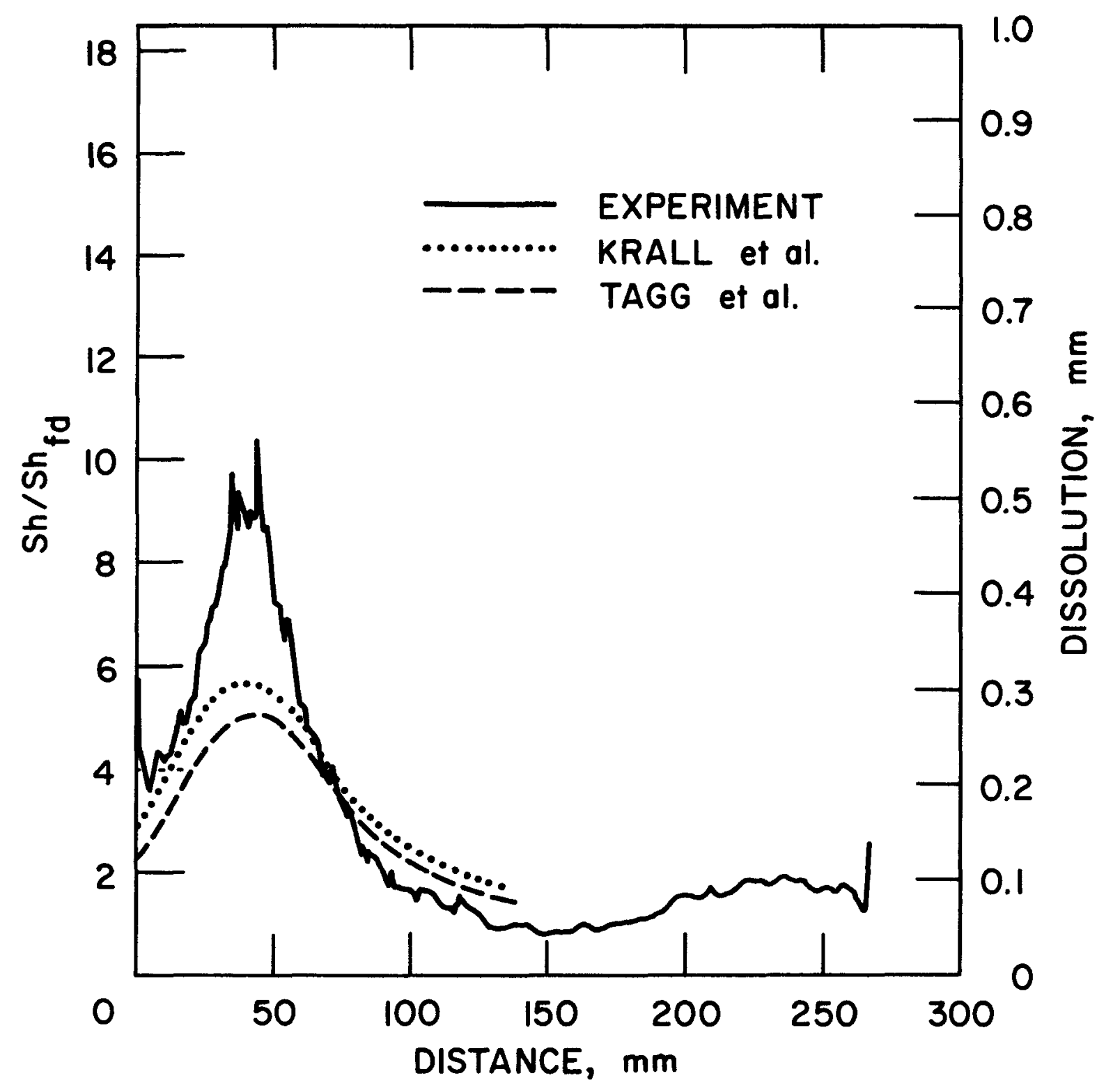

Fig. 7. Mass transfer data on orificed inlet pipe, Reference 12. 
In addition to the direct measurement of the mass transfer rates, the experiments reported ${ }^{11-14}$ also involved comparison with the erosion-corrosion models proposed by $\operatorname{Keller}^{15}$ and Bignold. ${ }^{16,17}$ The results support the theory that the observed pipe erosion-corrosion mechanism is essentially a dissolution process that is largely governed by the mass transfer aspect of the flow and the geometry.

An investigation was conducted at the CERL Mass Transfer Study Center to resolve the cause of enhancement of erosion-corrosion at a Spanish PWR station. 18 The severe erosion-corrosion occurred in the evaporator tubes of this power plant. The presence of a weld bead on the inner wall of the tubes upstream of a $180^{\circ}$ bend was suspected to cause metal loss downstream of the bead at two to three times the normal rate. The flow in the tubes was annular two-phase. A plaster-of-Paris model built at CERL indeed verified experimentally that the weld bead was the cause of the abnormal wear rate in the pipe. Figure 8 shows a photograph of the experimental evidence obtained on the bend wear. Figure 9 shows a sample case of the data obtained. On the basis of the information gathered in this study, it was also concluded that the evaporator tubes from another nuclear power plant (in Britain) would incur similar severe wear at the bends from upstream welds.

\section{CONCLUSIONS AND RECOMMENDATIONS}

(1) The new data on locally measured mass transfer rates in piping and other elements (entrances, elbows, restrictions) reveal that the link between the mass transfer coefficient and the resulting pipe wall wear is much stronger than was previously assumed.

(2) It is erroneous to work with the average, fully developed mass transfer values in correlating relative erosion-corrosion severity in pipe components and with mass transfer rates in the resolution of specific failure problems.

(3) It is equally erroneous to attribute a general geometry factor " $K$ " to complex piping interfaces to characterize their "propensity for erosioncorrosion." Although this procedure is allowable as a general-purpose engineering practice, it results in a nonconservative approach in designing specific geometries in critical cases. What is truly needed is 


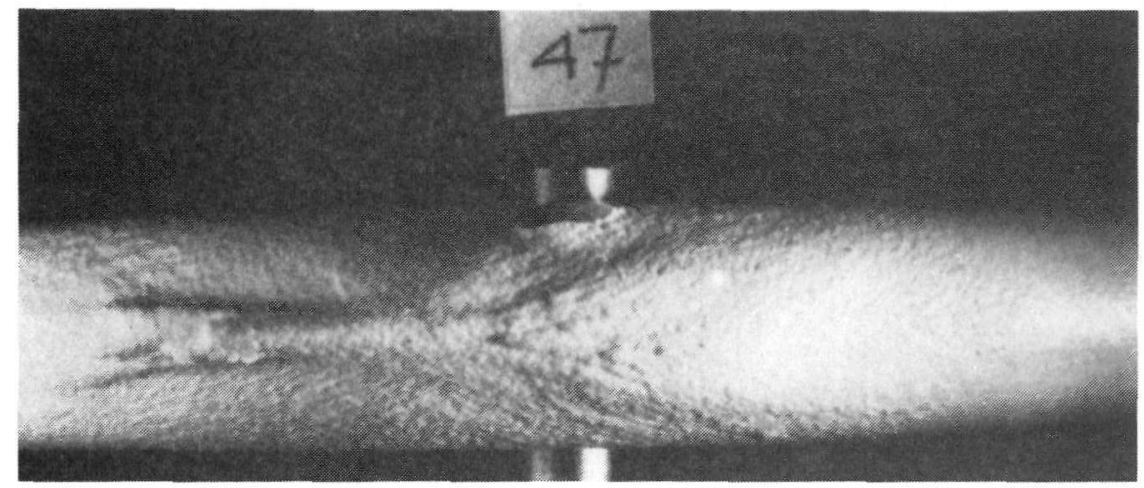

TEST $4(x=0.57)$ WITH WELD

TWOPHASE

FLOW

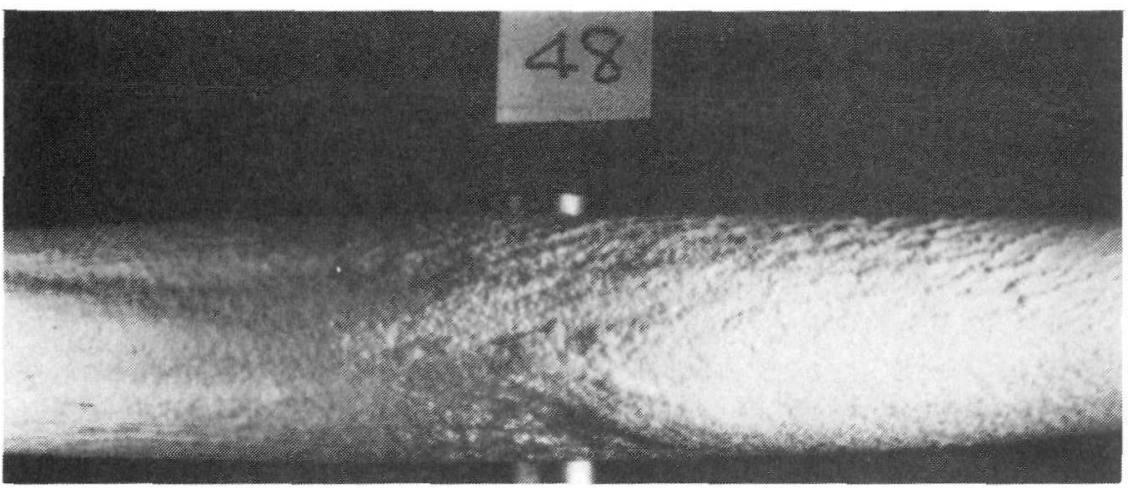

TEST $3(x=0.56)$ WITHOUT WELD

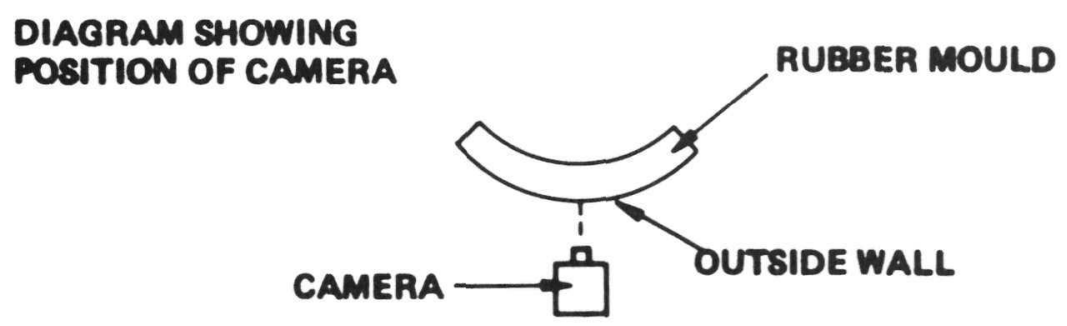

Fig. 8. Mass transfer on the outside wall of a bend caused by an upstream weld bead in a Spanish PWR, Reference 18. 


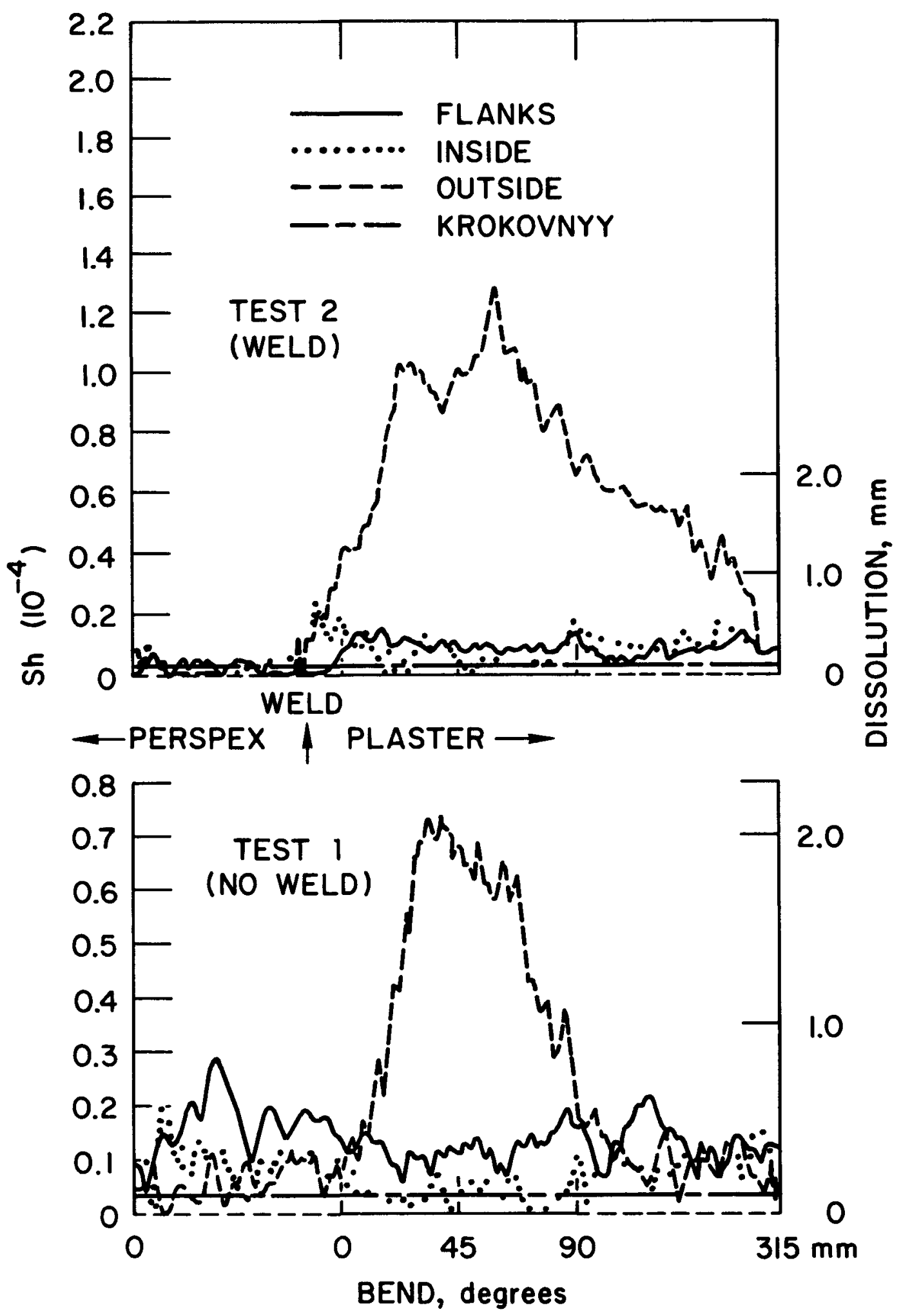

Fig. 9. Mass transfer data on the evaporator tube bend in a Spanish PWR, Reference 18. 
localized information on the mass transfer coefficients in these complex and critical interfaces (e.g., in the Surry pipe geometry).

(4) Specific geometries (such as splits, tees, and crosses), should be studied experimentally to obtain mass transfer maps on a local basis. In addition, various combinations of specific pipe elements should be tested with various spatial flow separations to identify configurations conducive to erosion-corrosion.

(5) Various techniques, among them the plaster dissolution technique, are available for the above studies. The plaster technique, as exemplified amply by the British work, is cheap and simple and lends itself to intricate casting. It is therefore highly recommended.

(6) A comprehensive multi-year program is needed to catalog the local data from such direct measurements on select critical geometries commonly found in power plant piping. Such data are woefully lacking and appear to be the key element in the resolution of erosion-corrosion concerns in PWR piping systems and in process industries.

\section{REFERENCES}

1. USNRC Office of Inspection and Enforcement, Feedwater Line Break, SSINS \#6835, 86-106, Supplement I (1986).

2. Allen, J. R. L., Bed Forms Due to Mass Transfer in Turbulent Flows: A Kaleidoscope of Phenomena, J. Fluid Mech., 49, (1), pp. 49-63 (1971).

3. Blumberg, P. N., and Curl, R. L., Experimental and Theoretical Studies of Dissolution Roughness, J. Fluid Mech., 65, (4), pp. 735-751 (1974).

4. Achenbach, E., "Mass Transfer From Bends of Circular Cross-Section to Air," in International Seminar on Future Energy Production - Heat and Mass-Transfer Problems, Dubrovnik, Yugoslavia, Vol. 1, pp. 327-337, Hemisphere Publishing Corp., Washington, D.C. (1976).

5. Choi, U. S., Talbot, L., and Cornet, I., Experimental Study of Wall Shear Rates in the Entry Region of a Curved Tube, J. Fluid Mech., 93, (3), pp. 465-489 (1979).

6. Metzger, D. E., and Larson, D. E., Use of Melting Point Surface Coatings for Local Convection Heat Transfer Measurements in Rectangular Channel Flows With 90-Deg Turns, ASME, J. of Heat Transfer, 108, pp. 48-54 (1986). 
7. Shemilt, L. W., and Shourky, E. I., "Aspects of Mass Transfer Analysis in Corrosion Systems, Heat and Mass Transfer in Metallurgical Systems," in 1979 Seminar of International Centre for Heat and Mass Transfer, Dubrovnik, Yugoslavia, Hemisphere Publishing Corp., Washington, D.C. (1981).

8. Sparrow, E. M. and Chrysler, G. M., Turbulent Flow and Heat Transfer in Bends of Circular Cross Section: I - Heat Transfer Experiments, ASME J. of Heat Transfer, 108, pp. 40-47 (1986).

9. Kuzay, T. M. and Kasza, K. E., Experiments and Analysis of Therma1 Striping Downstream of a Horizontal Pipe Elbow in Stratified Pipe Flow, ANS Trans. 49, pp. 459-460 (1985).

10. Coney, M. W. E., Erosion-Corrosion: The Calculation of Mass Transfer Coefficients, CERL RD/LIN 197/80 (May 1981).

11. Wilkin, S. J., Oates, H. S., and Coney, M. W. E., Mass Transfer in Straight Pipes and $90^{\circ}$ Bends Measured by the Dissolution of Plaster, CERL, TPRD/L/2469/N93 (May 1983).

12. Coney, M. W. E., Wilkin, S. J., and Oates, H. S., Thermal-Hydraulic Effects on Mass-Transfer Behavior and Erosion-Corrosion Metal Loss Rates, CERL, TPRD/L/2349/N82 (Jan. 1983).

13. Oates, H. S. and Wilkin, S. J ., Experimental Determination of Diffusion Coefficient for Plaster in Water by Spinning Disc Method, CERL, TPRD/L/2664/N84 (July 1984).

14. Wilkin, S. J. and Oates, H. S., Single-Phase Mass-Transfer in Straight Pipes at High Reynolds Numbers Using the Plaster Dissolution Method, CERL, TPRD/L/2752/N84 (Apr. 1985).

15. Keller, H., Problems de corrosion et d'erosion dans les turbines a vapeur saturee, J. Int. d'Etudes des Centrales Electrique, paper \#42 (1978).

16. Bignold, G. J., Garbett, K., Garnsey, R., and Woolsey, I. S., ErosionCorrosion in Nuclear Steam Generators, 2nd Int. Conf. on Water Chemistry of Nuclear Reactor Systems, Bournemarth (1980).

17. Bignold, G. J., et a1., CERL Single Phase Erosion-Corrosion Studies Under Boiled Feedwater Conditions, Workshop on Erosion-Corrosion of Carbon Steel Piping, Nuclear and Fossil Plants, EPRI, Palo Alto, CA (Apr. 1985).

18. Coney, M. W. E., private communication (TPRD/L/2734/N84, Feb. 1985). 
Distribution for NUREG/CR-5131 (ANL-88-20)

Interna1:
H. J. Halle
C. E. Till
K. E. Kasza
R. W. Weeks
ANL Patent File
T. M. Kuzay
W. J. Shack
ANL Libraries
E. M. Stefanski
ANL Contract File
TIS Files ( 3 )

\section{External:}

NRC, for distribution per R5 (315)

DOE-OSTI (10)

Manager, Chicago Operations Office, DOE

R. Dalton, DOE/CH

G. A. Arlotto, Office of Nuclear Regulatory Research, USNRC, Washington

C. Y. Cheng, Office of Nuclear Reactor Regulation, USNRC, Washington

G. Cragnolino, Brookhaven National Lab., Upton, NY 11973 (3)

C. J. Czajkowski, Dept. of Nuclear Engineering, Brookhaven National Laboratory, Upton, NY

W. S. Hazelton, Office of Nuclear Reactor Regulation, USNRC, Washington

O. Jonas, Jonas, Inc., 1113 Faun Road, Wilmington, DE 19803

R. L. Jones, Electric Power Research Inst., P. 0. Box 10412, Palo Alto, CA 94303

D. M. Norris, Electric Power Research Inst., P. O. Box 10412, Palo Alto, CA 94303

E. J. Rowley, Commonwealth Edison Co., P. O. Box 767, Chicago, IL 60690

A. Taboada, Office of Nuclear Regulatory Research, USNRC, Washington

B. Tomkins, Risley Nuclear Power Development Labs., U.K. Atomic Energy Authority, Riseley, Warrington, WA3 6 AT, England

E. Venerus, Knolls Atomic Power Laboratory, P. 0. Box 1072, Schenectady, NY 12301

J. R. Weeks, Brookhaven National Lab., Upton, NY 11973

K. R. Wichman, Office of Nuclear Reactor Regulation, USNRC, Washington

Materials and Components Technology Division Review Committee

P. Alexander

C. Li

L. Jardine

R. Scholl

S. Green

P. Shewmon

R. Greenkorn 


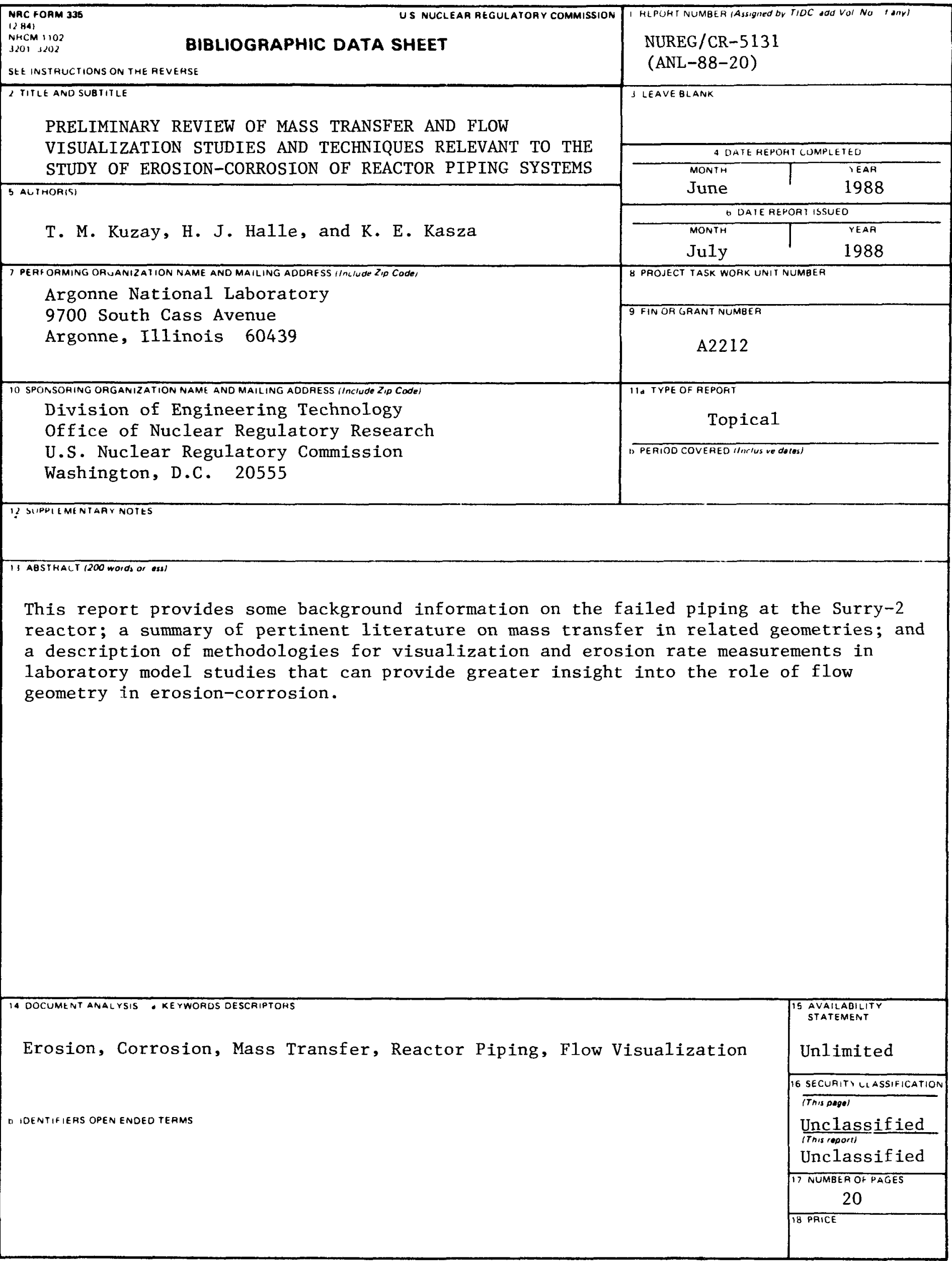

